Jurnal Akuntansi \& Manajemen

Vol 13, No. $2-2018,93-111$

\title{
Pengaruh Struktur Modal, Profitabilitas, Ukuran Perusahaan dan Modal Intelektual Terhadap Nilai Perusahaan Pada Indeks LQ 45 Periode 2010-2017
}

\author{
Roma Prima ${ }^{1}$, Rangga Putra Ananto ${ }^{2}$, Muhammad Rafi $^{3}$ \\ ${ }^{1}$ Jurusan Akuntansi, Politeknik Negeri Padang \\ Email:romaprima1@gmail.com \\ ${ }^{2} J u r u s a n$ Akuntansi, Politeknik Negeri Padang \\ Email: rangga@pnp.ac.id \\ ${ }^{3}$ Jurusan Akuntansi, Politeknik Negeri Padang \\ Email: muhammadrafi@pnp.ac.id
}

\begin{abstract}
This study aims to examine the effect of capital structure, profitability, firm size and intellectual capital towards firm value. Capital structure is proxied by Debt to Equity Ratio (DER), profitability is proxied by Return On Assets (ROA), company size is proxied by Ln from total assets, intellectual capital is proxied by Value Added Intellectual Coefficient (VAIC) and company value is proxied by Price to Book Value (PBV). The data used in this study is secondary data obtained from the company's financial statements on the $L Q$ 45 index listed on the Indonesia Stock Exchange for the period 2010-2017. The sampling technique was carried out using purposive sampling and obtained a sample of 15 companies. The data analysis technique used was multiple linear regression analysis using SPSS version 20. The results showed that the capital structure had no effect on the value of the company, profitability had an effect on the value of the company, the size of the company did not affect the value of the company and intellectual capital did not affect the value of the company.
\end{abstract}

Keywords: Capital Structure, Profitability, Firm Size, Intellectual Capital and Firm Value.

Penelitian ini bertujuan untuk menguji pengaruh struktur modal, profitabilitas, ukuran perusahaan dan modal intelektual terhadap nilai perusahaan. Struktur modal diproksikan dengan Debt to Equity Ratio (DER), profitabilitas diproksikan dengan Return On Asset (ROA), ukuran perusahaan diproksikan dengan Ln dari total aset, modal intelektual diproksikan dengan Value Added Intellectual Coefficient (VAIC) dan nilai perusahaan diproksikan dengan Price to Book Value (PBV). Data yang digunakan dalam penelitian ini adalah data sekunder yang diperoleh dari laporan keuangan perusahaan pada indeks LQ 45 yang terdaftar di Bursa Efek Indonesia periode 2010-2017. Teknik pengambilan sampel dilakukan dengan menggunakan purposive sampling dan diperoleh sampel sebanyak 15 perusahaan. Teknis analisis data yang digunakan adalah analisis regresi linear berganda dengan menggunakan SPSS versi 20. Hasil penelitian menunjukkan bahwa struktur modal tidak berpengaruh terhadap nilai perusahaan, profitabilitas berpengaruh terhadap nilai perusahaan, ukuran perusahaan tidak berpengaruh terhadap nilai perusahaan dan modal intelektual tidak berpengaruh terhadap nilai perusahaan. 
Kata kunci: Struktur Modal, Profitabilitas, Ukuran Perusahaan, Modal Intelektual dan Nilai Perusahaan.

\section{Pendahuluan}

Pada era globalisasi yang terjadi saat ini, para pelaku bisnis di dunia usaha semakin bersaing untuk dapat mencapai tujuan yang ingin dicapai oleh perusahaan. Pada umumnya, setiap perusahaan didirikan pasti memiliki tujuan tertentu, baik jangka pendek maupun jangka panjang. Tujuan jangka pendek perusahaan adalah untuk memperoleh laba atau keuntungan semaksimal mungkin dengan memanfaatkan berbagai sumber daya yang dimiliki perusahaan. Sedangkan tujuan jangka panjang perusahaan adalah untuk meningkatkan nilai perusahaan yang ditandai dengan tingkat kemakmuran para pemegang saham perusahaan. Nilai perusahaan juga merupakan tolak ukur bagi investor untuk menilai keberhasilan sebuah perusahaan. Nilai perusahaan dapat dilihat dari besarnya harga saham yang dimiliki oleh perusahaan. Semakin tinggi harga saham sebuah perusahaan, semakin tinggi pula nilai perusahaan tersebut (Nurkhin, dkk, 2017).

Perusahaan dalam mencapai tujuan utamanya yaitu memaksimumkan nilai perusahaan, terkadang tidak diimbangi dengan penggunaan modal perusahaan yang tepat terutama modal yang berasal dari utang. Penggunaan modal perusahaan yang berasal dari utang memiliki tingkat risiko yang lebih besar dibandingkan dengan modal yang dimiliki oleh perusahaan itu sendiri. Penggunaan modal perusahaan harus dilakukan secara optimal agar dapat meminimalkan risiko keuangan yang dapat terjadi (Suranto, dkk, 2017).

Struktur modal berkaitan dengan jumlah hutang dan modal sendiri yang digunakan untuk membiayai aset perusahaan. Struktur modal yang efektif mampu menciptakan kondisi keuangan yang kuat dan stabil. Penelitian yang dilakukan oleh Suranto, dkk (2017) menyatakan bahwa struktur modal yang diproksikan dengan DER berpengaruh positif terhadap nilai perusahaan. Sedangkan hasil penelitian yang berbeda ditunjukkan oleh Wulandari, dkk (2018) dan Lestari (2017) yang menemukan bahwa struktur modal yang juga diproksikan dengan DER tidak berpengaruh terhadap nilai perusahaan.

Faktor lain yang mempengaruhi tinggi rendahnya nilai perusahaan adalah kemampuan perusahaan dalam menghasilkan laba yang dinilai dengan rasio profitabilitas. Penilaian terhadap sejauh mana pertumbuhan profitabilitas perusahaan merupakan salah satu indikator penting bagi investor dalam menilai prospek perusahaan di masa depan. Profitabilitas dapat mencerminkan keuntungan dari investasi keuangan dengan sumber internal yang semakin besar, artinya profitabilitas berpengaruh terhadap nilai perusahaan. Semakin tinggi pertumbuhan profitabilitas perusahaan maka akan semakin baik pula nilai perusahaan (Andhieka dan Retnani, 2017). 
Selain beberapa indikator yang telah dijelaskan, ukuran perusahaan dianggap juga mampu mempengaruhi nilai perusahaan. Hal ini dapat disebabkan karena apabila semakin besar ukuran suatu perusahaan maka akan semakin mudah perusahaan mendapatkan sumber pendanaan, baik yang bersifat ekternal maupun internal. Penelitian yang dilakukan oleh Nurhayati (2013) ukuran perusahaan dinyatakan berhubungan positif terhadap nilai perusahaan. Namun, Dewi dan Wirajaya (2013) menemukan bahwa ukuran perusahaan tidak berpengaruh terhadap nilai perusahaan.

Indikator lainnya yang diyakini dapat mempengaruhi nilai perusahaan adalah modal intelektual. Perkembangan dunia bisnis saat ini, mengharuskan suatu perusahaan memiliki suatu kemampuan pengetahuan dan teknologi. Kemampuan perusahaan dalam bidang ilmu pengetahuan dan teknologi akan membuat perusahaan memiliki daya saing yang tinggi. Berbagai sumber daya yang langka dan berharga dapat diarahkan untuk menciptakan keunggulan bersaing, sehingga sumber daya yang dimiliki mampu bertahan lama dan tidak mudah ditiru, di transfer atau digantikan. Sumber daya yang dimiliki oleh perusahaan ini disebut modal intelektual.

Perusahaan yang digunakan dalam penelitian ini adalah perusahaan-perusahaan yang terdaftar dalam indeks LQ 45 tahun 2010-2017. Penulis memilih indeks LQ 45 karena indeks ini merupakan indeks yang terdiri dari 45 saham pilihan yang memiliki likuiditas tinggi dan kapitalisasi pasar yang besar serta diseleksi melalui beberapa kriteria pemilihan. Indeks ini di seleksi setiap enam bulan sekali, yaitu pada awal bulan Februari dan Agustus. Berdasarkan penjelasan diatas dan penelitian terdahulu yang masih terdapatnya perbedaan pengaruh antara variabel independen struktur modal, profitabilitas, ukuran perusahaan dan modal intelektual terhadap variabel dependen nilai perusahaan. Maka penulis merumuskan penelitian dengan judul: "Pengaruh struktur modal, profitabilitas, ukuran perusahaan dan modal intelektual terhadap nilai perusahaan : Pada Indeks LQ 45 periode 2010-2017”.

\section{Metode Penelitian}

\section{Desain penelitian}

Penelitian ini menggunakan pendekatan kuantitatif yaitu dengan menggunakan data yang berbentuk angka pada analisis statistiknya (Sugiyono, 2013). Penelitian ini bertujuan untuk mengetahui bagaimana pengaruh variabel independen yaitu struktur modal, profitabilitas, ukuran perusahaan dan intellectual capital terhadap variabel dependen yaitu nilai perusahaan.

\section{Definisi operasional variabel penelitian}

Variabel dependen dalam penelitian ini adalah nilai perusahaan, sedangkan variabel independennya adalah struktur modal, profitabilitas, ukuran perusahaan dan tiga komponen pembentuk Intellectual Capital yaitu Value Added Capital Employed (VACA), Value Added Human Capital (VAHU) dan Structural Capital Value Added 
(STVA). Untuk mempersingkat penjelasan definisi operasional dan pengukuran variabel, berikut adalah tabelnya:

Tabel 1. Definisi Operasional dan Pengukuran Variabel

\begin{tabular}{|c|c|c|c|c|}
\hline \multicolumn{2}{|c|}{ Variabel } & Definisi Operasional & Pengukuran & Skala \\
\hline $\begin{array}{l}\text { Variabel } \\
\text { Dependen }\end{array}$ & $\begin{array}{l}\text { Nilai } \\
\text { Perusahaan }\end{array}$ & $\begin{array}{l}\text { Nilai perusahaan atau } \\
\text { nilai pemegang } \\
\text { saham mencerminkan } \\
\text { reaksi pasar saham } \\
\text { terhadap perusahaan }\end{array}$ & PBV $=\frac{\text { Harga Saham }}{\text { Nilai Buku Saham }}$ & Rasio \\
\hline \multirow[t]{4}{*}{$\begin{array}{l}\text { Variabel } \\
\text { Independen }\end{array}$} & Struktur Modal & $\begin{array}{l}\text { Perbandingan antara } \\
\text { hutang jangka } \\
\text { panjang dengan } \\
\text { modal sendiri }\end{array}$ & DER $=\frac{\text { Total Hutang }}{\text { Total Ekuitas }} \times 100 \%$ & Rasio \\
\hline & Profitabilitas & $\begin{array}{l}\text { Kemampuan } \\
\text { perusahaan dalam } \\
\text { menghasilkan laba } \\
\text { selama periode } \\
\text { tertentu }\end{array}$ & $\mathrm{ROA}=\frac{\text { Laba bersih setelah pajak }}{\text { Total Aset }}$ & Rasio \\
\hline & $\begin{array}{l}\text { Ukuran } \\
\text { Perusahaan } \\
\text { (Size) }\end{array}$ & $\begin{array}{l}\text { Ukuran perusahaan } \\
\text { adalah skala untuk } \\
\text { menentukan besar } \\
\text { kecilnya perusahaan }\end{array}$ & Size $=\operatorname{Ln}$ Total Aset & Rasio \\
\hline & $\begin{array}{l}\text { Modal } \\
\text { Intelektual }\end{array}$ & $\begin{array}{l}\text { Sumber daya berupa } \\
\text { pengetahuan yang } \\
\text { tersedia pada } \\
\text { perusahaan yang } \\
\text { menghasilkan aset } \\
\text { bernilai tinggi dan } \\
\text { manfaat ekonomi di } \\
\text { masa mendatang bagi } \\
\text { perusahaan. }\end{array}$ & VAIC= VACA + VAHU + STVA & Rasio \\
\hline
\end{tabular}

\section{Populasi penelitian}

Populasi yang digunakan dalam penelitian ini adalah perusahaan yang termasuk ke dalam indeks LQ 45 selama periode 2010 hingga 2017.

\section{Sampel penelitian}

Metode pemilihan sampel yang digunakan dalam penelitian ini adalah purposive sampling. Dalam pemilihan sampel ini, terdapat beberapa kriteria yang akan ditetapkan pada penelitian ini antara lain :

a. Perusahaan pada indeks LQ 45 yang sudah dan masih terdaftar secara berturut-turut periode 2010 - 2017. 
b. Perusahaan yang tidak termasuk dalam sektor perbankan.

c. Perusahaan memiliki laba positif dalam setiap laporan keuangannya.

d. Perusahaan yang mempublikasikan laporan keuangan secara lengkap yang berkaitan dengan variabel penelitian.

Tabel 2. Penentuan Sampel Penelitian

\begin{tabular}{clc}
\hline No & \multicolumn{1}{c}{ Kriteria } & Jumlah Perusahaan \\
\hline 1. & Perusahaan yang secara konsisten terdaftar di indeks $L Q$ & 17 \\
& 45 pada 2010-2017 & $(2)$ \\
2. & Perusahaan yang temasuk sektor perbankan & - \\
3. & Perusahaan yang tidak memiliki laba positif & - \\
4. & Perusahaan yang tidak lengkap menampilkan variabel & $15 \times 8$ periode $=120$ \\
& penelitian & \\
\hline
\end{tabular}

\section{Tempat dan waktu penelitian}

Data yang digunakan dalam penelitian ini adalah data sekunder dari laporan keuangan perusahaan pada indeks LQ 45 periode 2010 hingga 2017. Waktu penelitian dilakukan pada bulan April sampai Agustus tahun 2018.

\section{Teknik pengumpulan data}

Data yang digunakan dalam penelitian ini adalah data sekunder yang dikumpulkan dengan cara metode dokumentasi. Laporan yang digunakan dalam penelitian ini adalah laporan keuangan tahunan perusahaan yang diperoleh melalui situs resmi BEI yaitu Indonesia Stock Exchange (www.idx.co.id).

\section{Teknik analisis data}

Seluruh penyajian dan analisis data yang digunakan pada penelitian ini menggunakan bantuan program SPSS 20.

1) Statistik deskriptif

Analisis statistik deskriptif adalah suatu pengolahan data yang bertujuan untuk memberikan gambaran atau deskripsi suatu data yang dilihat dari nilai ratarata (mean), standar deviasi, varian, maksimum, minimum, sum, range, kurtosis dan skewness (kemencengan distribusi) (Ghozali, 2016).

2) Uji asumsi klasik
a. Uji normalitas
b. Uji multikolinieritas
c. Uji autokorelasi
d. Uji heteroskedastisitas

3) Analisis regresi linier berganda 
Variabel independen dalam penelitian ini adalah struktur modal $\left(\mathrm{X}_{1}\right)$, profitabilitas $\left(\mathrm{X}_{2}\right)$, ukuran perusahaan $\left(\mathrm{X}_{3}\right)$, dan modal intelektual $\left(\mathrm{X}_{4}\right)$ sedangkan variabel dependen adalah nilai perusahaan $(\mathrm{Y})$ sehingga persamaan regresi bergandanya adalah :

$$
\mathrm{Y}=\alpha+\beta 1 X_{1}+\beta 2 X_{2}+\beta 3 X_{3}+\beta 4 X_{4}+\mathrm{e}
$$

Dimana:

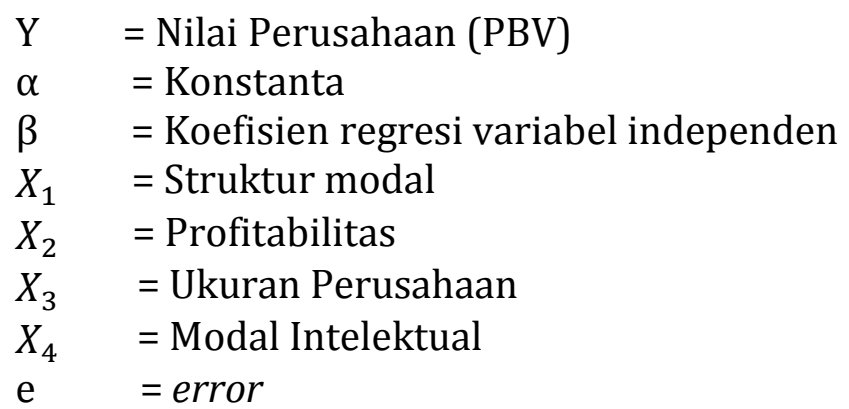

4) Uji hipotesis

a. Uji koefisien determinasi

Koefisien determinasi dapat dilihat pada tabel Model Summary pada tabel Adjusted R Square. Besarnya nilai Adjusted R Square menunjukkan seberapa besar variabel dependen dapat dijelaskan oleh variabel independen (Ghozali, 2016).

b. Uji statistik $\mathrm{F}$

Untuk menguji hipotesis ini digunakan uji statistik $\mathrm{F}$ dengan kriteria pengambilan keputusan apabila nilai signifikansi value $\mathrm{F}$ test $<0,05$ maka model regresi yang digunakan fit dan dapat digunakan untuk memprediksi pengaruh variabel independen terhadap variabel dependen secara keseluruhan.

c. Uji signifikan $t$

Kriteria pengujian yang digunakan dengan membandingkan nilai signifikan yang diperoleh dengan taraf signifikan yang telah ditentukan yaitu 0,05. Apabila nilai signifikan $<0,05$ maka variabel independen mampu mempengaruhi variabel dependen secara signifikan atau hipotesis diterima.

\section{Hasil dan Pembahasan}

\section{Analisis statistik deskriptif}

Berikut ini merupakan tabel analisis statistik deskriptif yang memberikan gambaran suatu data yang dilihat dari nilai minimum, maksimum, rata-rata, dan standar deviasi dari nilai variabel yang diuji: 
Tabel 3. Statistik Deskriptif

\begin{tabular}{lccccc}
\hline \multicolumn{5}{c}{ Descriptive Statistics } \\
\hline & $\mathrm{N}$ & Minimum & Maximum & Mean & Std. Deviation \\
\hline LAG_PBV & 119 & $-1,43$ & 6,70 & 1,1307 & 1,27254 \\
LAG_DER & 119 & $-1,87$ & 2,02 &, 2486 &, 38272 \\
LAG_ROA & 119 &,- 05 &, 21 &, 0505 &, 04551 \\
LAG_SIZE & 119 & 11,39 & 14,57 & 13,5520 &, 57201 \\
LAG_VAIC & 119 & $-3,52$ & 10,21 & 1,8163 & 1,65178 \\
Valid N (listwise) & 119 & & & \\
\hline \multicolumn{5}{c}{ Sumber : Pengolahan data SPSS 20 }
\end{tabular}

Tabel diatas menggambarkan deskripsi variabel-variabel yang digunakan dalam penelitian ini. Minimum yaitu nilai terkecil dari suatu rangkaian pengamatan, maksimum yaitu nilai terbesar dari suatu rangkaian pengamatan, mean (rata-rata) yaitu hasil penjumlahan nilai seluruh data dibagi banyak data, serta standar deviasi merupakan akar dari jumlah kuadrat dari selisih nilai data dengan rata-rata dibagi banyaknya data.

\section{Hasil pengujian asumsi klasik}

Uji asumsi klasik yang digunakan dalam penelitian ini adalah uji normalitas, uji multikolinieritas, uji heteroskedastisitas dan uji autokorelasi.

1) Uji normalitas

Uji normalitas menggunakan P-Plot Test yaitu melihat penyebaran titik pada sumbu diagonal dari grafik normal. Berikut adalah hasil uji normalitas dalam penelitian ini: 


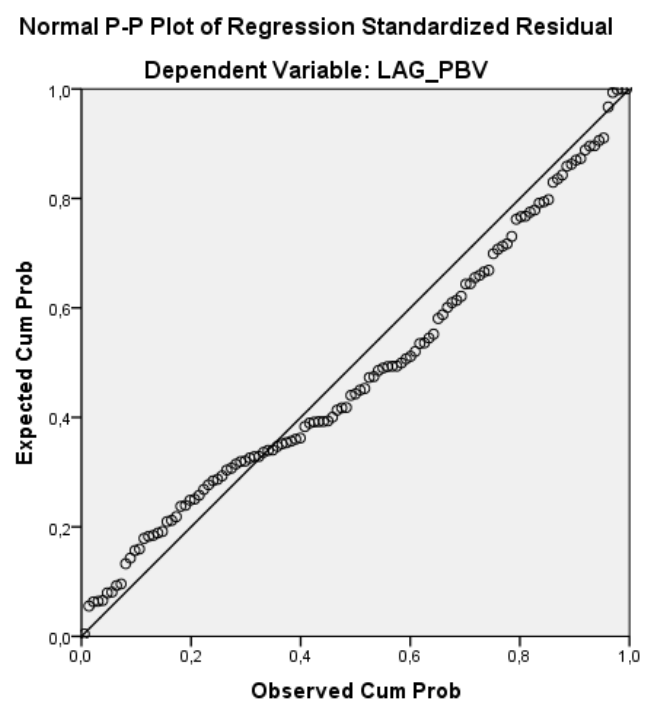

Gambar 1. Hasil Uji Normalitas

Sumber: Pengolahan data dengan SPSS 20

Berdasarkan grafik scatter plot normalitas diatas, terlihat bahwa titik-titik menyebar disekitar garis diagonal dan penyebarannya mengikuti arah garis diagonal. Selain itu, penulis juga menggunakan grafik histogram dalam menguji normalitas sebagai berikut:

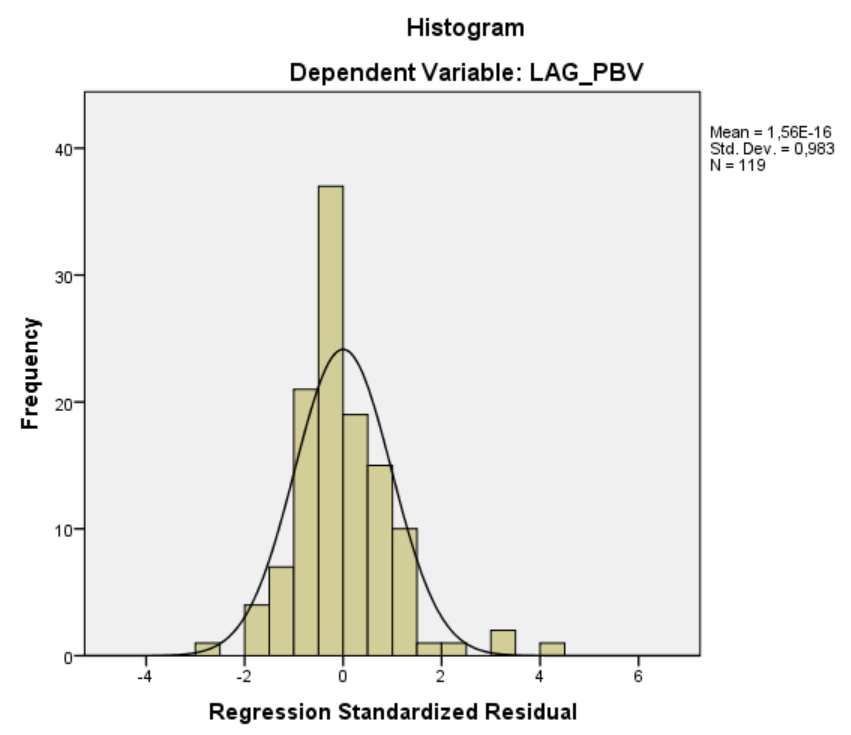

Gambar 2. Histogram Uji Normalitas

Sumber: Pengolahan data dengan SPSS 20

Selain menggunakan P-Plot Test, penulis juga menggunakan uji normalitas menggunakan One-Sample Kolmogorov-Smirnov Test. Berikut ini adalah hasil uji normalitas dalam penelitian ini: 
Tabel 4. Hasil Uji One-Sampel Kolmogorov-Smirnov Test

\begin{tabular}{llr}
\hline \multicolumn{2}{c}{ One-Sample Kolmogorov-Smirnov Test } \\
\hline $\mathrm{N}$ & \multicolumn{2}{c}{$\begin{array}{c}\text { Unstandardize } \\
\text { d Residual }\end{array}$} \\
Normal Parameters $\mathrm{a}, \mathrm{b}$ & Mean & 119 \\
& Std. Deviation & $0 \mathrm{E}-7$ \\
Most Extreme Differences & Absolute & 1,19089972 \\
& Positive &, 094 \\
& Negative &, 094 \\
Kolmogorov-Smirnov Z & &,- 066 \\
Asymp. Sig. (2-tailed) & 1,026 \\
\hline a. Test distribution is Normal. &, 243 \\
b. Calculated from data. &
\end{tabular}

Sumber : Pengolahan data SPSS 20

Dari tabel diatas, dapat dilihat nilai signifikasinya atau Asymp. Sig. (2-tailed) sebesar 0,243 yang menunjukkan bahwa nilai signifikan $>0,05$. Dengan demikian nilai residualnya terdistribusi secara normal, sehingga menunjukkan bahwa penelitian ini dinyatakan telah memenuhi kriteria uji normalitas.

2) Uji multikolinieritas Salah satu cara untuk mengetahui ada atau tidaknya multikolonieritas ini adalah dengan menggunakan Variance Inflation Factor (VIF) dan Tolerance. Berikut adalah hasil uji multikolonieritas dalam penelitian ini:

Tabel 5. Hasil Uji Multikolinieritas

\begin{tabular}{|c|c|c|c|c|c|c|c|c|}
\hline \multicolumn{9}{|c|}{ Coefficients $^{a}$} \\
\hline \multirow{2}{*}{\multicolumn{2}{|c|}{ Model }} & \multicolumn{2}{|c|}{$\begin{array}{c}\text { Unstandardized } \\
\text { Coefficients }\end{array}$} & \multirow{2}{*}{$\begin{array}{c}\begin{array}{c}\text { Standardized } \\
\text { Coefficients }\end{array} \\
\text { Beta }\end{array}$} & \multirow[t]{2}{*}{$t$} & \multirow[t]{2}{*}{ Sig. } & \multicolumn{2}{|c|}{$\begin{array}{l}\text { Collinearity } \\
\text { Statistics }\end{array}$} \\
\hline & & $B$ & $\begin{array}{l}\text { Std. } \\
\text { Error }\end{array}$ & & & & Tolerance & VIF \\
\hline \multirow[t]{5}{*}{1} & (Constant) & 1,719 & 3,107 & &, 553 & ,581 & & \\
\hline & LAG_DER & ,272 & ,344 & 082 & 789 & ,432 & ,716 & 1,396 \\
\hline & LAG_ROA & 7,170 & 3,093 & 256 & 2,318 & 022 & 628 & 1,593 \\
\hline & LAG_SIZE &,- 092 & ,229 &,- 041 &,- 401 & 689 & ,727 & 1,375 \\
\hline & LAG_VAIC & ,124 &, 076 & 161 & 1,622 & 108 & ,784 & 1,276 \\
\hline
\end{tabular}

a. Dependent Variable: LAG_PBV

Sumber: Pengolahan data SPSS 20

Berdasarkan tabel 5 diatas dapat diketahui bahwa hasil uji multikolonieritas menunjukkan nilai tolerance di atas 0,1 dan nilai variance inflation factor (VIF) di bawah 10 untuk setiap variabel. Berdasarkan hasil uji multikolonieritas, dapat disimpulkan bahwa semua variabel independen dalam model regresi tidak terdapat korelasi antara variabel yang satu dengan lainnya, sehingga variabel independen tersebut layak digunakan dalam penelitian ini.

3) Uji autokorelasi 
Model regresi yang baik adalah model regresi yang bebas dari masalah autokorelasi. Salah satu cara yang dapat digunakan untuk mendeteksi adanya autokorelasi adalah uji Durbin-watson. Berikut adalah hasil uji autokorelasi:

Tabel 6. Hasil Uji Autokorelasi

\begin{tabular}{lccccc}
\hline \multicolumn{5}{c}{ Model Summary } \\
\hline Model & $\mathrm{R}$ & R Square & $\begin{array}{c}\text { Adjusted R } \\
\text { Square }\end{array}$ & $\begin{array}{c}\text { Std. Error of } \\
\text { the Estimate }\end{array}$ & Durbin-Watson \\
\hline 1 &, $449^{a}$ &, 202 &, 174 & 1,4892525 &, 858 \\
\hline $\begin{array}{l}\text { a. Predictors: (Constant), VAIC, SIZE, DER, ROA } \\
\text { b. Dependent Variable: PBV }\end{array}$ & Sumber: Pengolahan data SPSS 20 &
\end{tabular}

Berdasarkan hasil autokorelasi pada tabel 6 diatas, terlihat bahwa nilai Durbin-Watson (DW) sebesar 0,858, sehingga terjadi masalah autokorelasi. Untuk mengatasi masalah tersebut, penulis menggunakan metode Cochrane Orcutt dengan cara me-Lag variabel dependen dan independen. Berikut ini adalah hasil uji autokorelasi setelah menggunakan metode Cochrane Orcutt:

Tabel 7. Hasil Uji Autokorelasi dengan Metode Cochrane Orcutt

\begin{tabular}{lccccc}
\hline \multicolumn{5}{c}{ Model Summary } \\
\hline Model & $\mathrm{R}$ & $\mathrm{R}$ Square & $\begin{array}{c}\text { Adjusted R } \\
\text { Square }\end{array}$ & $\begin{array}{c}\text { Std. Error of } \\
\text { the Estimate }\end{array}$ & Durbin-Watson \\
\hline 1 &, $352^{\text {a }}$ &, 124 &, 093 & 1,21161 & 2,111 \\
\hline a. Predictors: (Constant), LAG_VAIC, LAG_DER, LAG_SIZE, LAG_ROA & \\
b. Dependent Variable: LAG_PBV \\
Sumber: Pengolahan data SPSS 20
\end{tabular}

Dari tabel 7 diatas dapat dilihat bahwa nilai Durbin-Watson (DW) sebesar 2,111. Hal ini berarti nilai DW berada diantara DU dan 4-DU, yaitu $1,771<2,111$ $<2,229$. Sehingga dapat disimpulkan bahwa model regresi bebas dari autokorelasi.

4) Uji heteroskedastisitas

Dalam penelitian ini uji heteroskedastisitas dilakukan dengan melakukan uji park. Berikut ini adalah hasil dari uji heteroskedastisitas: 


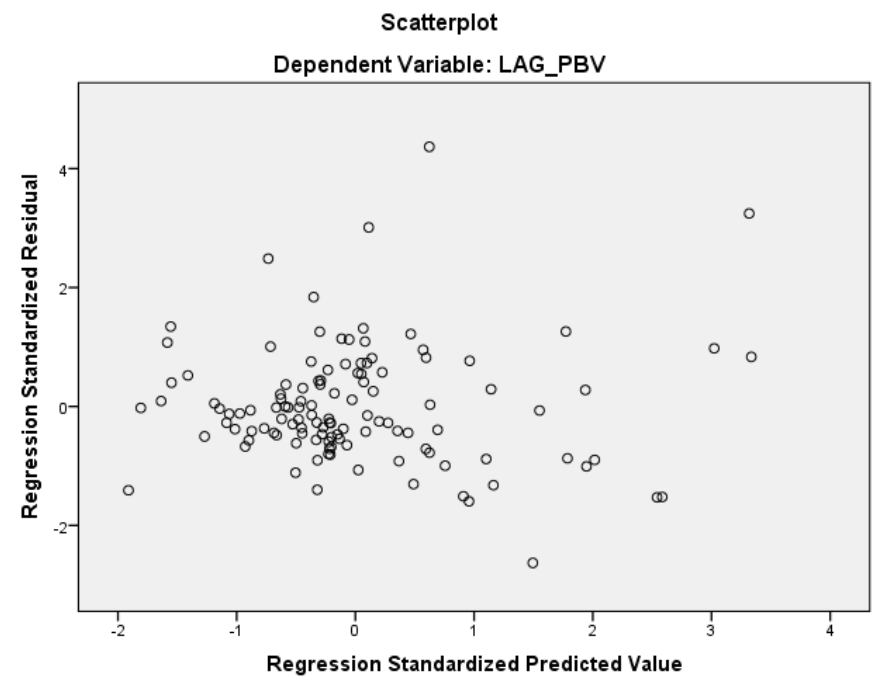

Gambar 3. Hasil Uji Heteroskedastitas

Sumber: Pengolahan data SPSS 20

Berdasarkan grafik scatterplot diatas terlihat bahwa titik-titik menyebar secara acak serta tersebar baik di atas maupun dibawah angka 0 pada sumbu Y. Hal ini dapat disimpulkan bahwa tidak terjadi heteroskedastisitas pada model regresi, sehingga layak dipakai untuk memprediksi PBV berdasarkan masukan variabel independen DER, ROA, SIZE dan VAIC.

Selain menggunakan grafik scatterplot, penulis juga menggunakan uji statistik yaitu uji rank spearman untuk menguji gejala heteroskedastisitas. Berikut ini adalah hasil uji rank spearman dalam penelitian ini:

Tabel 8. Hasil Uji Heteroskedastisitas

\begin{tabular}{|c|c|c|c|c|c|c|}
\hline & & LAG_DER & LAG_ROA & LAG_SIZE & LAG_VAIC & $\begin{array}{c}\text { Unstandardized } \\
\text { Residual }\end{array}$ \\
\hline LAG_DER & Sig. (2-tailed) & &, 000 &, 000 &, 024 & ,323 \\
\hline LAG_ROA & Sig. (2-tailed) & ,000 & & ,015 & ,000 & 943 \\
\hline LAG_SIZE & Sig. (2-tailed) & ,000 & ,015 & & ,741 & ,706 \\
\hline LAG_VAIC & Sig. (2-tailed) & ,024 & ,000 & ,741 & & 840 \\
\hline Unstandardized & & & & & & \\
\hline Residual & Sig. (2-tailed) & ,323 & 943 & ,706 & 840 & \\
\hline
\end{tabular}

Dari tabel 4.7 dapat disimpulkan bahwa tidak terjadi heteroskedastisitas dalam penelitian ini, hal ini disebabkan karena nilai Sig. pada kolom Unstandardized Residual yang diperoleh dalam uji heteroskedastisitas $>0,05$. 


\section{Analisis regresi linier berganda}

Analisis linear berganda digunakan untuk manguji pengaruh dua atau lebih variabel independen terhadap variabel dependen.

\section{Hasil koefisien determinasi}

Berikut hasil uji koefisien determinasi dalam penelitian ini:

$$
\text { Tabel 9. Koefisien Determinasi }
$$

\begin{tabular}{lcccc}
\multicolumn{5}{c}{ Model Summaryb } \\
\hline Model & $\mathrm{R}$ & R Square & $\begin{array}{c}\text { Adjusted R } \\
\text { Square }\end{array}$ & $\begin{array}{c}\text { Std. Error of } \\
\text { the Estimate }\end{array}$ \\
\hline 1 &, $352^{\text {a }}$ &, 124 &, 093 & 1,21161 \\
\hline a. Predictors: (Constant), LAG_VAIC, LAG_DER, LAG_SIZE, LAG_ROA \\
b. Dependent Variable: LAG_PBV \\
Sumber: Pengolahan SPSS 20
\end{tabular}

Hasil output SPSS pada tabel 9 diatas menunjukkan besarnya adjusted $R$ Square adalah 0,093. Hal ini berati bahwa 9,3\% variasi PBV dapat dijelaskan oleh variasi keempat variabel independen DER, ROA, SIZE, VAIC. Sedangkan sisanya 90,7\% (100\%-9,3\%) dijelaskan oleh faktor-faktor lainnya yang tidak dijelaskan dalam model penelitian.

\section{Hasil uji statistik F}

Berikut hasil uji F dalam penelitian ini:

Tabel 10. Hasil Uji Statistik F

\begin{tabular}{clccccc}
\multicolumn{7}{c}{ ANOVA $^{\mathrm{a}}$} \\
\hline Model & & Sum of & $\mathrm{df}$ & Mean Square & $\mathrm{F}$ & Sig. \\
& & Squares & & & & \\
\hline 1 & Regression & 23,733 & 4 & 5,933 & 4,042 &, $004^{\mathrm{b}}$ \\
& Residual & 167,353 & 114 & 1,468 & & \\
& Total & 191,086 & 118 & & & \\
\hline
\end{tabular}

a. Dependent Variable: LAG_PBV

b. Predictors: (Constant), LAG_VAIC, LAG_DER, LAG_SIZE, LAG_ROA

Sumber: Pengolahan SPSS 20

Berdasarkan tabel 4.9 hasil uji F, didapat nilai $F$ hitung sebesar 4,042 dengan probabilitas (signifikan) 0,004. Karena signifikan jauh lebih kecil dari 0,05, maka menunjukkan bahwa model regresi yang digunakan fit, dan dapat menggambarkan pengaruh variabel independen terhadap variabel dependen secara keseluruhan. 


\section{Hasil uji t}

Berikut ini adalah hasil uji t:

Tabel 11. Hasil Uji t

\begin{tabular}{lccccc}
\hline \multicolumn{7}{c}{ Coefficients $^{\text {a }}$} \\
\hline Model & \multicolumn{2}{c}{$\begin{array}{c}\text { Unstandardized } \\
\text { Coefficients }\end{array}$} & $\begin{array}{c}\text { Standardized } \\
\text { Coefficients }\end{array}$ & T & Sig. \\
\hline \multicolumn{7}{c}{ B } & $\begin{array}{c}\text { Std. } \\
\text { Error }\end{array}$ & Beta & & \\
\hline 1 (Constant) & 1,719 & 3,107 & &, 553 &, 581 \\
LAG_DER &, 272 &, 344 &, 082 &, 789 &, 432 \\
LAG_ROA & 7,170 & 3,093 &, 256 & 2,318 &, 022 \\
LAG_SIZE &,- 092 &, 229 &,- 041 &,- 401 &, 689 \\
LAG_VAIC &, 124 &, 076 &, 161 & 1,622 &, 108 \\
\hline
\end{tabular}

a. Dependent Variable: LAG_PBV

Sumber : Pengolahan data SPSS 20

a. Hasil Uji Hipotesis 1

Hipotesis yang pertama dalam penelitian ini yaitu struktur modal (DER) berpengaruh terhadap nilai perusahaan (PBV). Pengujian hipotesis ini dilakukan untuk menguji apakah struktur modal mempengaruhi nilai perusahaan.

b. Hasil Uji Hipotesis 2

Hipotesis yang kedua dalam penilitian ini yaitu profitabilitas (ROA) berpengaruh terhadap nilai perusahaan (PBV). Pengujian hipotesis ini dilakukan untuk menguji apakah profitabilitas mempengaruhi nilai perusahaan.

c. Hasil Uji Hipotesis 3

Hipotesis yang ketiga dalam penelitian ini yaitu ukuran perusahaan (SIZE) berpengaruh terhadap nilai perusahaan (PBV). Pengujian hipotesis ini dilakukan untuk menguji apakah ukuran perusahaan mempengaruhi nilai perusahaan.

d. Hasil Uji Hipotesis 4

Hipotesis yang keempat dalam penelitian ini yaitu modal intelektual (VAIC) berpengaruh terhadap nilai perusaan (PBV). Pengujian hipotesis ini dilakukan untuk menguji apakah modal intelektual mempengaruhi nilai perusahaan.

Berdasarkan tabel 4.10 diatas menghasilkan model regresi sebagai berikut:

$$
P B V=1,719+0,272 X_{1}+7,170 X_{2}-0,092 X_{3}+0,124 X_{4}
$$

Keterangan: 


$$
\begin{aligned}
& \mathrm{X}_{1}=\text { Struktur modal (DER) } \\
& \mathrm{X}_{2}=\text { Profitabilitas (ROA) } \\
& \mathrm{X}_{3}=\text { Ukuran perusahaan (SIZE) } \\
& \mathrm{X}_{4}=\text { Modal intelektual (VAIC) }
\end{aligned}
$$

\section{Analisisi hasil pengujian}

a. Struktur modal berpengaruh terhadap nilai perusahaan

Hipotesis pertama dalam penelitian ini adalah struktur modal berpengaruh terhadap nilai perusahaan. Dalam toeri trade off theory dijelaskan bahwa jika manfaat yang dihasilkan lebih besar dari pengorbanan yang timbul sebagai akibat penggunaan hutang, maka porsi hutang dapat ditambahkan. Namun, dalam penelitian ini hasil penelitian menunjukan bahwa tinggi atau rendahnya dari struktur modal yang diproksikan dengan DER tidak mempengaruhi nilai perusahaan, hal ini menunjukan bahwa hasil penelitian tidak sesuai dengan teori yang ada.

Hal ini dikarenakan perusahaan indeks LQ 45 adalah jajaran 45 perusahaan terbaik dari semua perusahaan yang tercatat di pasar modal. Salah satu kategori yang menjadi aspek penilaian adalah perusahaan yang memiliki tingkat likuiditas dan kapitalisasi pasar yang tinggi, hal ini menunjukkan bahwa para pelaku pasar modal percaya dan tidak melihat nilai perusahaan pada indeks LQ 45 berdasarkan dari struktur modal yang dimiliki oleh perusahaan. Hal inilah yang membuat struktur modal yang diproksikan dengan DER tidak berpengaruh terhadap nilai perusahaan.

b. Profitabilitas berpengaruh terhadap nilai perusahaan

Hipotesis kedua dalam penelitian ini adalah profitabilitas berpengaruh terhadap nilai perusahaan. Dalam teori profitabilitas menjelaskan bahwa semakin besar tingkat laba bersih yang dihasilkan oleh perusahaan maka akan meningkatkan harga saham perusahaan yang nantinya akan meningkatkan nilai perusahaan. Laba dijadikan sebagai indikator penentu baik atau buruknya hasil kinerja sebuah perusahaan dalam mengelola sumber daya modal yang dimiliki. Investor akan mencari suatu perusahaan yang mengalami peningkatan daya tarik dari segi profitnya, artinya perusahaan yang mempunyai tingkat profit yang tinggi di setiap periodenya maka akan semakin besar pula tingkat pengembalian bagi investor untuk mendapatkan timbal balik dari perusahaan atau yang disebut sebagai dividen. Kecenderungan investor dalam memilih perusahaan yang memiliki ROA yang tinggi akan mempengaruhi harga saham yang nantinya akan mempengaruhi nilai perusahaan.

c. Ukuran perusahaan berpengaruh terhadap nilai perusahaan

Hipotesis ketiga dalam penelitian ini adalah ukuran perusahaan berpengaruh terhadap nilai perusahaan. Dalam teori ukuran perusahaan dianggap dapat mempengaruhi nilai perusahaan karena semakin besar ukuran atau skala perusahaan makan akan semakin mudah pula perusahaan memperoleh sumber 
pendanaan, baik yang bersifat internal maupun eksternal. Perusahaan yang memiliki ukuran perusahaan yang besar, tidak menentukan perusahaan tersebut memiliki kinerja yang bagus untuk kedepannya. Hal inilah yang menyebabkan investor tidak menjadikan ukuran perusahaan sebagai faktor yang menentukan keputusan berinvestasi.

d. Modal intelektual berpengaruh terhadap nilai perusahaan Hipotesis keempat dalam penelitian ini adalah modal intelektual berpengaruh terhadap nilai perusahaan. Teori pertama, yaitu teori stakeholder menjelaskan bahwa dalam upaya menciptakan nilai bagi perusahaan, manajemen perusahaan harus dapat mengolah seluruh sumber daya yang dimiliki perusahaan, baik karyawan (human capital), aset fisik (physical capital) maupun structural capital. Hasil penelitian menunjukan bahwa besar kecilnya modal intelektual suatu perusahaan tidak menyebabkan nilai perusahaan meningkat, artinya hasil penelitian tidak sesuai dengan teori. Penyebab hasil penelitian ini tidak sesuai dengan teori adalah banyak investor yang masih menggunakan faktor-faktor lain dalam mengambil keputusan berinvestasi, seperti faktor retensi kepemilikan,faktor fundamental yang dicapai, tingkat keuntungan dan ketentuan perusahaan dalam membagikan deviden dari pada menjadikan modal intelektual dalam menghasilkan keputusan investasi (Andhieka dan Retnani, 2017).

Dari hasil analisis pengujian yang dilakukan maka diperoleh ringkasan sebagai berikut:

Tabel 12. Ringkasan Hasil Pengujian

\begin{tabular}{|c|c|c|}
\hline \multirow[b]{2}{*}{ No. } & \multirow[b]{2}{*}{ Variabel Independen } & Variabel Dependen \\
\hline & & Nilai Perusahaan \\
\hline 1 & Struktur Modal & $\bar{X}$ \\
\hline 2 & Profitabilitas & $\sqrt{ }$ \\
\hline 3 & Ukuran Perusahaan & $\mathrm{X}$ \\
\hline 4 & Modal Intelektual & $\mathrm{X}$ \\
\hline
\end{tabular}

Keterangan:

$\sqrt{ }=$ variabel independen yang berpengaruh terhadap variabel dependen atau

hipotesis diterima

$\mathrm{X}=$ variabel independen tidak berpengaruh terhadap variabel dependen atau

hipotesis ditolak.

\section{Kesimpulan dan Saran}

Berdasarkan hasil analisis data, pengujian, dan pembahasan, maka dapat disimpulkan sebagai berikut: 
1. Struktur modal merupakan variabel pertama dari variabel independen yang dihitung dengan Debt to Equity Ratio (DER), hasil penelitian menunjukan bahwa struktur modal tidak berpengaruh terhadap nilai perusahaan dengan kata lain $\mathrm{H}_{1}$ ditolak. Hal ini menunjukan bahwa setiap kenaikan Debt to Equity Ratio (DER) tidak akan memberikan pengaruh terhadap Price to Book Value (PBV).

2. Profitabilitas merupakan variabel kedua dari variabel independen yang dihitung dengan Return On Asset (ROA), hasil penelitian menunjukan bahwa profitabilitas berpengaruh terhadap nilai perusahaan dengan kata lain $\mathrm{H}_{2}$ diterima. Hal ini menunjukan bahwa setiap kenaikan Return On Asset (ROA) akan menaikan Price to Book Value (PBV).

3. Ukuran perusahaan merupakan variabel ketiga dari variabel independen yang dihitung dengan $\log$ natural dari total aset. Hasil penelitian menunjukan bahwa ukuran perusahaan tidak berpengaruh terhadap nilai perusahaan, dengan kata lain $\mathrm{H}_{3}$ ditolak. Hal ini menunjukan setiap kenaikan ukuran perusahaan tidak menaikan Price to Book Value (PBV).

4. Modal intelektual merupakan variabel keempat dari variabel independen yang dihitung dengan Value Added Intellectual Coeficient (VAIC), hasil penelitian menunjukan bahwa modal intelektual tidak berpengaruh terhadap nilai perusahaan, dengan kata lain $\mathrm{H}_{4}$ ditolak. Hal ini menunjukan setiap kenaikan VAIC tidak menaikan Price to Book Value (PBV).

\section{Referensi}

[1] Brigham, E.F., dan Houston. [2011]. Dasar-Dasar Manajemen Keuangan. Edisi 1. Salemba Empat, Jakarta.

[2] Deegan., dan Unerman. [2006]. Financial Accounting Theory. McGraw-Hill

[3] Fahmi, Irham. [2014]. Manajemen Keuangan Perusahaan dan Pasar Modal. Mitra Wacana Media, Jakarta.

[4] Ghozali, Imam. [2016]. Aplikasi Analisis Multivariate Dengan Program IBM SPSS 21. Edisi 7. Badan Penerbit UNDIP, Semarang

[5] Ikatan Akuntan Indonesia. [2009]. Standar Akuntansi Keuangan Per 1 Juli 2009. Penerbit Salemba Empat, Jakarta.

[6] Abidin, Zainal., Meina Wulansari Yusniar., dan Muhammad Ziyad. 2012. Pengaruh Struktur Modal, Kebijakan Dividen, dan Size Terhadap Nilai 
Perusahaan (Studi pada Perusahaan Properti di Bursa Efek Indonesia). Jurnal Wawasan Manajemen. Vol. 2, Nomor 3.

[7] Aida, Rahma Nurul., dan Evi Rahmawati. 2015. Pengaruh Modal Intelektual dan Pengungkapannya Terhadap Nilai Perusahaan: Efek Intervening Kinerja Perusahaan. Jurnal Akuntansi Universitas Muhammadiyah Yogyakarta.

[8] Andhieka, Krisnayana Tio., dan Endang Dwi Retnani. 2017. Pengaruh Profitabilitas dan Modal Intelektual Terhadap Nilai Perusahaan. Jurnal Ilmu dan Riset Akuntansi. Vol.06 No.09.

[9] Astuti, D. D., dan Hotima, C. 2016. Variabel yang Mempengaruhi Struktur Modal dengan Profitabilitas sebagai Variabel Intervening (Studi pada Industri Manufaktur di Bursa Efek Indonesia). Dinamika Global, ISSN: 398-413.

[10] Dewi., Ayu Sri Mahatma., dan Ary Wirajaya. 2013. Pengaruh Struktur Modal, Profitabilitas dan Ukuran Perusahaan Pada Nilai Perusahaan. E-Jurnal Akuntansi Universitas Udayana. ISSN: 2302-8556

[11] Fauzia, N., dan Amanah, L. 2016. Pengaruh Intellectual Capital, Karakteristik Perusahaan, dan Corporate Social Responsibility Terhadap Nilai Perusahaan. Jurnal Ilmu dan Riset Akuntansi, 5(4), 1-22.

[12] Fransiskus, Randa., dan Ariyanto Solon. 2012. Pengaruh Modal Intelektual Terhadap Nilai Perusahaan (Studi Empiris pada Perusahaan Manufaktur yang Terdaftar di Bursa Efek Indonesia), Jurnal Sistem Informasi Manajemen dan Akuntansi, Vol 10 No 1. Fakultas Ekonomi UAJ Makassar, 2012, hal. 29

[13] Hidayati, Eva Eko. 2010. Analisis Pengaruh DER, DPR, ROE, dan Size Terhadap PBV Perusahaan Manufaktur yang Listing di BEI periode 2005-2007. Universitas Diponegoro.

[14] Lestari. 2017. Pengaruh Kepemilikan Institusional dan Struktur Modal Terhadap Nilai Perusahaan. Jurnal Riset Manajemen dan Bisnis Fakultas Ekonomi UNIAT. Vol.02.

[15] Nurhayati, Mafizatun. 2013. Profitabilitas, Likuiditas dan Ukuran Perusahaan Pengaruhnya Terhadap Kebijakan Dividen dan Nilai Perusahaan Sektor Non Jasa. Jurnal Keuangan dan Bisnis. Vol.05 No.02.

[16] Nurkhin, Ahmad., Agus Wahyudi., dan Anisa Septiani Aenul Fajriah. 2017. Relevansi Struktur Kepemilikan Terhadap Profitabilitas dan Nilai Perusahaan Barang Konsumsi. Jurnal Akuntansi Multiparadigma. Vol 8 No 1. 
[17] Pambudi, Nindya Mawarni., dan Andayani. 2017. Pengaruh Modal Intelektual dan Indeks Pengungkapan Modal Intelektual Terhdap Nilai Perusahaan. Jurnal Ilmu dan Riset Akuntansi. Vol.06 No.05. ISSN: 2460-0585

[18] Pertiwi, Nita Tiyas., dan Maswar Patuh Priyadi. 2016. Pengaruh Profitabilitas, Kepemilikan Manajerial, DER dan FCF Terhadap Nilai Perusahaan Melalui DPR. Jurnal Ilmu dan Riset Akuntansi. Vol05 No.02

[19] Prasetyanto, Pramundityo., dan Anis Chariri. 2013. Pengaruh Struktur Kepemilikan dan Kinerja Intellectual Capital Terhadap Nilai Perusahaan. Jurnal Akuntansi Diponegoro. Vol.02 No.02.

[20] Pulic, A. 1998. Measuring the Performance of Intellectual Potential in Knowledge Economy. Paper presented at the $2^{\text {nd }}$ McMaster Word Congress on Measuring and Managing Intellectual Capital by the Asutrian Team for Intellectual Potential.

[21] Pulic, A. 2000. VAICTM — an Accounting Tool for IC Management.

[22] Putri, Merliya Triyana. 2017. Pengaruh Profitabilitas dan Keputusan Investasi Terhadap Nilai Perusahaan Pulp \& Paper yang Terdaftari di BEI. Vol. 4 No. 2

[23] Rina, Hj. Tjandrakirana. D. P., dan Monika, M. 2014. Pengaruh Kinerja Keuangan Terhadap Nilai Perusahaan pada Perusahaan Manufaktur yang Terdaftar di Bursa Efek Indonesia. Manajemen dan Bisnis Sriwijaya, 12(1). 116.

[24] Rudangga, I Gusti Ngurah Gede., dan Gede Merta Sudiarta. 2016. Pengaruh Ukuran Perusahaan, Leverage dan Profitabilitas Terhadap Nilai Perusahaan. E-Jurnal Manajemen Unud. Vol.5 No.7.

[25] Sriastutik, Wahyu., dan Maswar Patuh Priyadi. 2017 Pengaruh Intellectual Capital, Pengungkapan Intellectual Capital dan Karakteristik Perusahaan Terhadap Nilai Perusahaan. Jurnal Ilmu dan Riset Akuntansi. Vol.06 No.12. ISSN: 2460-0585.

[26] Sudibya, D. C. N. A., dan M. D. Restuti. 2014. Pengaruh Modal Intelektual terhadap Nilai Perusahaan dengan Kinerja Keuangan sebagai Variabel Intervening. Jurnal Manajemen dan Bisnis. Vol. 18, (1): 14-29.

[27] Suranto, Vintia Ayu Hayuningthias Maramis., Grace B. Nangol., dan Stanley Kho Walondouw. 2017. Analisis Pengaruh Struktur Modal dan Kinerja Keuangan Terhadap Nilai Perusahaan Pada Perusahaan Perbankan di Bursa Efek Indonesia. Jurnal EMBA. Vol.05 No.02 
[28] Ulum, Ihyaul. 2008. Pengaruh Intellectual Capital Terhadap Kinerja Keuangan Perusahaan Perbankan di Indonesia. Tesis. UNDIP Diponegoro. Semarang.

[29] Wulandari, Desi., Patricia Dhiana., dan Agus Suprianto. 2018. Pengaruh Modal Intelektual, Struktur Modal, Profitabilitas Terhadap Nilai Perusahaan dengan Kinerja Keuangan sebagai Variabel Intervening. Vol. 04, No. 04. ISSN: 25027967. 